\title{
Kinetics of epsilon antitoxin antibodies in different strategies for active immunization of lambs against enterotoxaemia ${ }^{1}$
}

\author{
Heni F. Costa ${ }^{2}$, Selene D. Babboni², Carlos F.C. Rodrigues ${ }^{3}$, Carlos R. Padovani ${ }^{4}$, \\ Iveraldo S. Dutra ${ }^{5}$, Silvana C. Paulan ${ }^{5}$ and José R. Modolo ${ }^{2 *}$
}

\begin{abstract}
Costa H.F., Babboni S.D., Rodrigues C.F.C., Padovani C.R., Dutra I.S., Paulan S.C. \& Modolo J.R. 2013. Kinetics of epsilon antitoxin antibodies in different strategies for active immunization of lambs against enterotoxaemia. Pesquisa Veterinária Brasileira 33(8):979-982. Departamento de Higiene Veterinária e Saúde Pública, Escola de Medicina Veterinária e Zootecnia, Universidade Estadual Paulista, Distrito de Rubião Júnior s/n, Cx. Postal 524, Botucatu, SP 18618-970, Brazil. E-mail: jrmodolo@fmvz.unesp.br

Enterotoxaemia, a common disease that affects domestic small ruminants, is mainly caused by the epsilon toxin of Clostridium perfringens type D. The present study tested four distinct immunization protocols to evaluate humoral response in lambs, a progeny of non-vaccinated sheep during gestation. Twenty-four lambs were randomly allocated into four groups according to age $(7,15,30$ and 45 days), receiving the first dose of epsilon toxoid commercial vaccine against clostridiosis with booster after 30 days post vaccination. Indirect ELISA was performed after the first vaccine dose and booster to evaluate the immune response of the lambs. Results showed that for the four protocols tested all lambs presented serum title considered protective $(\geq 0.2 \mathrm{UI} / \mathrm{ml}$ epsilon antitoxin antibodies $)$ and also showed that the anticipation of primovaccination of lambs against enterotoxaemia conferred serum title considered protective allowing the optimization of mass vaccination of lambs.
\end{abstract}

INDEX TERMS: Clostridium perfringens type D, epsilon antitoxin, ELISA, clostridiosis, immunizatiom, enterotoaemia.

RESUMO.- [Cinética dos anticorpos antitoxina epsilon em diferentes estratégias de imunização ativa em cordeiros contra a enterotoxemia.] Enterotoxemia, uma das mais comuns enfermidades que acomete os pequenos ruminantes domésticos, é causada principalmente pela toxina épsilon de Clostridium perfringens tipo D. 0 presente

\footnotetext{
${ }^{1}$ Received on March 8, 2013.

Accepted for publication on June 26, 2013.

${ }^{2}$ Departamento de Higiene Veterinária e Saúde Pública, Faculdade de Medicina Veterinária e Zootecnia, Universidade Estadual Paulista (Unesp), Campus Botucatu, Cx. Postal 524, Botucatu, SP 18618-970, Brazil. *Corresponding author: jrmodolo@fmvz.unesp.br

${ }^{3}$ Unidade de Pesquisa e Desenvolvimento, Agência Paulista de Tecnologia dos Agronegócios (APTA), Rodov. Gladys Bernardes Minhoto Km 62, Itapetininga, SP 18200-970, Brazil.

${ }^{4}$ Departamento de Bioestatística, Instituto de Biociências, Universidade Estadual Paulista (Unesp), Campus Botucatu, Cx. Postal 524, Botucatu, SP, Brazil.

${ }^{5}$ Departamento de Apoio, Produção e Saúde Animal, Faculdade de Medicina Veterinária, Unesp, Rua Clóvis Pestana 793, Araçatuba, SP 16050680, Brazil.
}

estudo avaliou a resposta humoral conferida por quatro protocolos distintos de primovacinação na progênie de ovelhas não vacinadas durante a gestação. Vinte e quatro cordeiros foram aleatoriamente divididos em quatro grupos de acordo com a idade (dias) que receberam a primeira dose da vacina comercial contra clostridiose contendo toxóide epsilon na sua formulação. Todos os cordeiros foram vacinados aos 7, 15, 30 ou 45 dias de idade e receberam um reforço da dose 30 dias após a vacinação. A avaliação sorológica dos cordeiros pelo teste de ELISA indireto foi realizada por ocasião da administração da primeira dose da vacina. Os resultados elucidaram não haver comprometimento da resposta imune de cordeiros vacinados tanto aos 7, 15, 30 ou 45 dias de idade associada ao reforço da dose 30 dias após, demonstrando assim que a antecipação da primeira vacinação conferiu proteção aos cordeiros contra a enterotoxemia, permitindo otimizar o planejamento da vacinação em massa dos cordeiros.

TERMOS DE INDEXAÇÃO: Clostridium perfringens tipo D, antitoxina épsilon, ELISA, clostridiose, imunização, enterotoxemia. 


\section{INTRODUCTION}

Epsilon exotoxin (ETX), if overproduced by Clostridium perfringens type $\mathrm{B}$ and $\mathrm{D}$ due to the intestinal flora imbalance (Finnie 2003), causes severe enterotoxaemia in small ruminants (Summers et al. 1995, Uzal 2004, Songer 2010). Enterotoxaemia affects sheep of all ages, but is most common in lambs between 3-10 weeks old under good nutritional conditions (Kriek et al. 1994, Smith \& Sherman 1994, Songer 1998). Although natural exposure to ETX can stimulate epsilon antitoxin production, it is not enough to promote protection when enterotoxaemia is triggered (Griner 1961, Blackwell et al. 1983,). Thus, periodic and systematic vaccination of herd with epsilon toxoid becomes an important measure associated with the correct handling of the animals (Kriek et al. 1994, Uzal \& Kelly 1999, Lobato et al. 2000).

Vaccination of sheep is recommended in the last month of pregnancy and for lambs 4-10 weeks old (Radostits et al. 2002). Although the minimum amount of toxoid is mentioned in commercial vaccines against clostridiosis, studies which evaluate the ideal toxoid concentration as vaccine effectiveness under field conditions and sheep serological response, mainly in progeny non-vaccinated during gestation, are scarce. In this context, the present work aimed to evaluate the humoral response in lambs using four different immunization protocols for first vaccine dose.

\section{MATERIALS AND METHODS}

The experimental use of animals (mice and sheep) in this study was approved by the Animal Ethics Committee (CEUA-57/2008) of the School of Veterinary Medicine and Animal Husbandry, Unesp-Botucatu.

Twenty-four zootechnical bookkeeping pregnant ewes, up to 24 months old and with no history of vaccination against clostridiosis, were selected from a commercial Texel sheep flock. After birth, all lambs remained with the ewes and were randomly allocated into four groups of different ages $(7,15,30$ and 45 days old) to receive the first vaccine dose against enterotoxaemia.

The commercial vaccine used in this study consisted of bacterial-toxoid of Clostridium chauvoei, Clostridium septicum, Clostridium perfringens types B, C and D, Clostridium novyi, Clostridium sordellii and Clostridium tetani. The epsilon toxoid concentration per vaccine dose was sufficient to induce a serum titer of at least $0.5 \mathrm{UI} / \mathrm{ml}$ in rabbits. In order to ensure the scientific and ethical quality of this study, the vaccine brand name was not disclosed.

All lambs were first vaccinated at $7,15,30$ or 45 days of age and received a booster post vaccination. Blood samples were collected from jugular vein immediately after the first vaccination and at 30 and 60 days subsequently.

Epsilon-protoxin produced in house by the Animal Infectious Diseases Laboratory of FMVA-Unesp, Araçatuba/SP (Veschi 2006) was used as antigen. Antigen toxigenicity was assessed by observing symptoms in Balb-c mice (mean weight 17-20g) inoculated intravenously with trypsin-activated $(0.05 \%)$ epsilon prototoxin at different dilutions (Miyata et al. 2001, Uzal et al. 2002), as well as by analysis of protein fraction through $12 \%$ polyacrylamide gel electrophoresis (SDS-PAGE) (Asubel et al. 1994) and by homologous antitoxin neutralization.

The homologous positive control serum (containing $180 \mathrm{UI} /$ $\mathrm{ml}$ of $C$. perfringens type D epsilon antitoxin) was kindly provided by the Laboratory of Reference Material Production National
Agricultural Laboratory-LANAGRO, localized in Pedro Leopoldo/ $\mathrm{MG}$, and the negative control was obtained from newborn lambs deprived of colostrum at birth.

Sheep serum samples were tested individually by indirect ELISA (Enzyme-linked immunosorbent assay), in duplicate, using the method described by Uzal et al. (1997) with modifications. Microtitration plates (NUNC ${ }^{\circledR}$ Maxisorp Demark) were coated with $100 \mu \mathrm{l} /$ well of antigen diluted in carbonate-bicarbonate buffer $(0.06 \mathrm{M}, \mathrm{pH} 9.6)$ at $4^{\circ} \mathrm{C}$ overnight in a humidified chamber. Blocking was done by $5 \%$ of skimmed milk diluted in carbonate-bicarbonate buffer $(0.06 \mathrm{M}, \mathrm{pH} 9.6)$. After incubation at $37^{\circ} \mathrm{C}$ for 1 hour serum samples diluted 1:200 in phosphate buffer (PBS 0.01M, pH 7.2 , Tween $20^{\circledR} 0.05 \%$ ) were added following incubation at $37^{\circ} \mathrm{C}$ for 1 hour. Peroxidase labeled anti-sheep IgG produced in donkey (Sigma ${ }^{\circledR}$ A-3415) diluted 1:8000 in PBS/Tween $20^{\circledR} 0.05 \%$ and incubated at $37^{\circ} \mathrm{C}$ for 1 hour. Between each immunoassay stage, microplates were washed four times with PBS/Tween $20^{\circledR} 0.05 \%$, pH 7.4 in a Multiskan Wash ${ }^{\circledR}$ plate washer. The 2,20?-Azino-bis (3-ethylbenzothiazoline-6-sulfonic acid, Sigma ${ }^{\circledR}$-A3219) was used as substrate and the reaction as stopped after 10 minutes by $1 \%$ lauryl sodium dodecyl sulfate, $98.5 \%$ GC (Sigma ${ }^{\circledR}$ L-3771). Microplates were read by Multiskan MCC/330 (Labsystem ${ }^{\circledR}$ ) photometer at $405 \mathrm{~nm}$.

The indirect ELISA interpretation was based on the following formula: $\mathrm{A} / \mathrm{P}=(\mathrm{XA}-\mathrm{XN}) /(\mathrm{XP}-\mathrm{XN})$; which $\mathrm{A} / \mathrm{P}$ is the final absorbance value for the test sample, $\mathrm{XA}$ is the mean optical density (OD) for the test serum, and XN and XP are the mean OD values for the negative and positive control sera, respectively. Absorbance values in $\mathrm{UI} / \mathrm{ml}$ were calculated using a linear regression curve built with the ELISA results obtained from five positive control sera of different known titers $(180 \mathrm{UI} / \mathrm{ml})$. Animals with antibody titers equal to or greater than $0.2 \mathrm{UI} / \mathrm{ml}$ were considered as protected (Blackwell et al. 1991).

Non-parametric variance analysis for repeated measures with Dunn's test was used to compare independent groups. Significance level was set at 5\% (Zar 2009).

\section{RESULTS}

Epsilon toxin antigenic identity used in indirect ELISA was confirmed by the neutralization in mice, complemented by the identification of a $32 \mathrm{kDa}$ protein band by SDS-PAGE.

Serological evaluation of the lambs, after the first vaccine dose, showed better results for 30-day-old animals which presented antibody levels $(0,712 \pm 0,100 \mathrm{IU} / \mathrm{ml})$ $(\mathrm{p}<0,05)$ above those vaccinated at 7,15 or 45 days of age $(0,437 \pm 0,318 ; 0,341 \pm 0,162 ; 0,452 \pm 0,303 \mathrm{IU} / \mathrm{ml}$, respectively) (Table 1 ).

Similar antibody levels were observed for all groups evaluated after 30 days from the first vaccine dose (booster) $(\mathrm{p}>0.05)$.

However, difference was observed 30 days after the booster $(\mathrm{p}<0.05)$ only for 7 days old vaccinated lambs, which presented antibody level below the other groups $(0.341 \pm 0.163 \mathrm{IU} / \mathrm{ml})$. Thus, 15,30 and 45 days old lamb groups presented antibody level above the protective threshold arbitrarily fixed at $0.15 \mathrm{IU} / \mathrm{ml}$ (Table 1).

\section{DISCUSSION}

Enterotoxaemia is a disease caused by epsilon toxin, produced by Clostridium perfringens type $\mathrm{D}$ and causes intense economic losses in sheep farming. Young lambs confined 
Table 1.Descriptive measures of epsilon antitoxin serum antibodies (UI/ml), determined by indirect ELISA in lambs submitted to three different protocols of primovaccination using a polyvalent vaccine against clostridiosis constituted of epsilon toxoid

\begin{tabular}{|c|c|c|c|}
\hline \multirow{2}{*}{$\begin{array}{c}\text { First vaccine } \\
\text { dose (age in days) }\end{array}$} & \multicolumn{3}{|c|}{ Serological evaluation (days after first vaccination) } \\
\hline & 0 & 30 & 60 \\
\hline & \multicolumn{3}{|c|}{ Median (minimum value; maximum value) Average \pm standard deviation } \\
\hline \multirow[t]{2}{*}{7} & $0,369(0,028 ; 0,888)^{\mathrm{c}}$ & $0,127(0,051 ; 0,643)^{\mathrm{c}}$ & $0,324(0,180 ; 0,545)^{\mathrm{d}}$ \\
\hline & $0,437 \pm 0,318$ & $0,281 \pm 0,272$ & $0,341 \pm 0,163$ \\
\hline \multirow[t]{2}{*}{15} & $0,348(0,069 ; 0,578)^{\mathrm{b}}$ & $0,332(0,218 ; 0,468)^{\mathrm{a}}$ & $0,739(0,554 ; 0,818)$ \\
\hline & $0,341 \pm 0,162$ & $0,336 \pm 0,105$ & $0,712 \pm 0,100$ \\
\hline \multirow[t]{2}{*}{30} & $0,739(0,554 ; 0,818)^{\mathrm{b}}$ & $0,456(0,228 ; 0,706)$ & $0,652(0,410 ; 0,936)$ \\
\hline & $0,712 \pm 0,100$ & $0,437 \pm 0,184$ & $0,658 \pm 0,207$ \\
\hline \multirow[t]{2}{*}{45} & $0,494(0,092 ; 0,838)^{\mathrm{b}}$ & $0,277(0,214 ; 0,471)^{\mathrm{a}}$ & $0,662(0,575 ; 0,842)$ \\
\hline & $0,452 \pm 0,303$ & $0,300 \pm 0,093$ & $0,691 \pm 0,105$ \\
\hline
\end{tabular}

and subjected to high energy diets present elevated risk of initiate the disease symptomatology (Songer 2010). Among the epidemiological aspects of type D sheep enterotoxaemia, even being a disease that affects animals of all ages, young lambs under good corporal conditions and in their first weeks of age, are particularly the most susceptible (Kriek et al. 1994). Thereby, a strategy using immunization by colostrum must be considered in control programs, as demonstrated by Costa et al. (2012), that vaccinated pregnant ewes 30 days before parturition, allowing the transfer of colostral antibodies specific enough to guarantee the immunity considered protective $(0.15 \mathrm{IU} / \mathrm{ml})$ of the newborn lamb against enterotoxaemia until its entry into the feedlot, with 60 days of age. According to Radostits et al. (2002), the recommended age for receiving the first vaccine dose against this disease is 4 weeks old, with booster at 10 weeks of age.

In the present study it was observed that precocious vaccine allowed enough immunity for lamb protection. The 7 days old vaccination protocol presented the lower epsilon antitoxin antibody level $(0,341 \pm 0,163 \mathrm{UI} / \mathrm{ml})$ after booster compared to the other protocols (15; 30 e 45 days of age), however resulted in a satisfactory protection above the protective threshold fixed at $0.15 \mathrm{IU} / \mathrm{ml}$ (Blackwell et al. 1991) of lambs. Besides no evidence was observed for the inability of antibodies production assigned to the young lambs by interference of colostral antibodies (Griner 1961, Tizard 2004).

Lambs vaccinated at 30 or 45 days of age presented higher concentration of antitoxin epsilon serum antibodies for protocols of 7 and 15 days of age. This can be explained by the animal response to the vaccine as well as by the possibility of subclinical infection cases, due to the epsilon toxin produced lifelong by Clostridium perfringens type D (Uzal et al. 2002).

Furthermore, lambs presented great immune response post booster vaccination which stimulated the production of epsilon toxin neutralizing antibodies $(\mathrm{p}<0.05)$ (Table 1).

Post booster antibodies elevation is an important characteristic of conventional or experimental active immunization against clostridiosis (Sterne \& Warrack 1964, Jan- sen 1967, Troxel et al. 1997, Araújo et al. 2010, Curci et al. 2010) with direct impact on vaccination program effectiveness for this important ruminant illness group.

The present study showed no differences between immunes responses to primovaccination at $7,15,30$ or 45 days of life, associated to booster after 30 days, of lambs were progeny of ewes free of vaccination against clostridiosis. Emphasized on importance of immunization and booster to ensure satisfactory protection above the protective threshold minimum to lambs during study.

\section{CONCLUSION}

The present study showing that the vaccine anticipation of lambs, progeny from non-vaccinated ewes during gestation against enterotoxaemia, provides serum title considered protective, allowing the optimization of mass vaccination of lambs.

Acknowledgements.- To FAPESP (Grant \#2008/10957-2), CNPq (Edital Universal \#27/2007, Grant \#550806/2008-3) for financial support. To APTA (SIGA: NRP-3202); to Prof. Cáris Maroni Nunes and Prof. Guilherme de Paula Nogueira, Araçatuba School of Veterinary Medicine, Unesp; to Dr. Mariano Fernandez-Miykawa of INTA, Bariloche, Argentina; and to sheep raisers Gian Carlo Cilento Filho, Walter Gavião, and Rubem Osta.

\section{REFERENCES}

Araújo R.F., Curci V.C.L.M., Nóbrega F.L.C., Ferreira R.M.M. \& Dutra I.S. 2010. Vaccination protocol and bacterial strain affect the serological response of beef calves against blackleg. Pesq. Vet. Bras. 30:554-558.

Ausubel F.M., Brent R., Kingston R.E., Moore D.D., Seidman J.G., Smith J.A. \& Struhl K. 1994. Current protocols in molecular biology. Greene Publishing Associates and John Wiley and Sons, New York. 5300p.

Blackwell T.E., Butler D.G., Prescott J. \& Wilcox B. 1991. Differences in signs and lesions in sheep and goats with enterotoxaemia induced by intraduodenal infusion of Clostridium perfringens type D. Am. J. Vet. Res. 52:1147-1152.

Blackwell T.E., Butler D.G. \& Bell J.A. 1983. Enterotoxaemia in the goat: the humoral response and local tissue reaction following vaccination with two different bacterin-toxoids. Can. J. Comp. Med. 47:127-132.

Costa H.F., Babboni S.D., Rodrigues C.F.C., Padovani C.R., Dutra I.S. \& Modolo J.R. 2012. Cinética dos anticorpos de origem colostral contra a toxina épsilon de Clostridium perfringens tipo D em cordeiros. Pesq. Vet. Bras. 32:17-21. 
Curci V.C.M., Nogueira A.H.C., Nóbrega F.L.C., Araújo R.F., Perri S.H.V., Cardoso T.C. \& Dutra I.S. 2010. Neonatal immune response of Brazilian beef cattle to vaccination with Clostridium botulinum toxoids types C and D by indirect ELISA. J. Venom. Anim. Toxins Trop. Dis. 16:509-513.

Finnie J.W. 2003. Pathogenesis of brain damage produced in sheep by Clostridium perfringens type D epsilon toxin: a review. Aust. Vet. J. 81:219221.

Griner L.A. 1961. Enterotoxaemia of sheep. III. Clostridium perfringens type D antitoxin titres of normal, novaccinated lambs. Am. J. Vet. Res. 22:447-448

Jansen B.C. 1967. The duration of immunity of pulpy kidney disease of sheep. Onderstepoort J. Vet. Res. 34:333-334.

Kriek N.P.J., Odendaal M.W. \& Hunter P. 1994. Clostridium perfringens type D enterotoxaemia, p.1314-1322. In: Coetzer J.A.W., Thomson G.R. \& Tustin R.C. (Eds), Infections Diseases of Livestock with Special Reference to Southern Africa. Vol.2. Oxford University Press, Cape Town.

Lobato F.C.F., Moro E., Umehara O., Assis R.A., Martins N.E. \& Gonçalves L.C.B. 2000. Avaliação da resposta de antitoxinas beta e épsilon de Clostridium perfringens induzidas em bovinos e coelhos por seis vacinas comerciais no Brasil. Arq. Bras. Med. Vet. Zootec. 52:313-318.

Miyata S., Matsushita O., Minami J., Katayama S., Shimamoto S. \& Okabe A. 2001. Cleavage of a C-terminal peptide is essential for heptamerization of Clostridium perfringens epsilon-toxin in the synaptosomal membrane. J. Biol. Chem. 276:13778-13783.

Radostits O.M., Gay C.C., Blood D.C. \& Hinchcliff K.W. 2002. Doenças causadas por bactérias - Clostridium, p.653-656. In: Ibid. (Eds), Clínica Veterinária: um tratado de doenças de bovinos, ovinos, suínos, caprinos e equinos. 9aㅡ ed. Guanabara Koogan, Rio de Janeiro.

Smith M.C. \& Sherman D.M. 1994. Enterotoxaemia, p.289-305. In: Smith M.C. \& Sherman D.M. (Eds), Goat Medicine. Lea and Febiger, Pennsylvania.
Songer J.G. 1998. Clostridial diseases of small ruminants. Vet. Res. 29:219232.

Songer J.G. 2010. Clostridia as agents of zoonotic disease. Vet. Microbiol. 140:399-404.

Summers B.A., Cummings J.F. \& deLahunta A. 1995. Veterinary Neuropathology. Mosby, St Louis, p.269-270.

Sterne M. \& Warrack G.H. 1964. The types of Clostridium perfringens. J. Pathol. Bacteriol. 88:279-283.

Tizard I.R. 2004. Veterinary Immunology: an introduction. $7^{\text {th }}$ ed. W.B. Saunders, London. 494p.

Troxel T.R., Burke G.L., Wallace W.T., Keaton L.W., McPeake S.R., Smith D. \& Nicholson I. 1997. Clostridial vaccination efficacy on stimulating and maintaining an immune response in beef cows and calves. J. Anim. Sci.75:19-25.

Uzal F.A. 2004. Diagnosis of Clostridium perfringens intestinal infections in sheep and goats. Anaerobe 10:135-143.

Uzal F.A. \& Kelly W.R. 1999. Serum antibody responses to a Clostridium perfringens epsilon toxóide vaccine in goats. Anaerobe 5:287-289.

Uzal F.A., Kelly W.R., Morris W.E. \& Assis R.A. 2002. Effects of intravenous injection of Clostridium perfringens type D epsilon toxin in calves. J. Comp. Pathol. 126:71-75.

Uzal F.A., Kelly W.R. \& Nielsen K. 1997. Detection of Clostridium perfringens type $\mathrm{D}$ epsilon antitoxin in serum of goats by competitive and indirect ELISA. Vet. Microbiol. 51:223-231.

Veschi J.L.A. 2006. Eficácia de vacina experimental contra a enterotoxaemia causada pela toxina épsilon do Clostridium perfringens tipo D em caprinos. Tese de Doutorado, Faculdade de Ciências Agrárias e Veterinárias, Universidade Estadual Paulista, Jaboticabal, SP. 67p.

Zar J.H. 2009. Biostatistical Analysis. $5^{\text {th }}$ ed. Prentice Hall, New Jersey. $994 p$. 